\title{
Grzegorz Masik
}

Uniwersytet Gdański

e-mail: geomg@univ.gda.pl

\section{KONCEPCJE I BADANIA ODPORNOŚCI GOSPODARCZEJ REGIONÓW}

\section{CONCEPTS AND RESEARCH OF ECONOMIC RESILIENCE OF REGIONS}

DOI: $10.15611 /$ pn.2017.477.15

JEL Classification: P48, R1, R58

Streszczenie: Celem artykułu jest przegląd koncepcji i badań dotyczących odporności gospodarczej. Istnieją trzy podstawowe interpretacje decydujące o zakresie analiz: odporność inżynieryjna, ekologiczna i adaptatywna. W ramach wyróżnionych koncepcji odporności bada się podążanie regionów do stanu równowagi, ich funkcjonowanie jako złożonych i adaptatywnych systemów oraz wdrażane w przeszłości strategie pozwalające budować ich odporność na zakłócenia zewnętrzne. Badania z tego zakresu skupiają się na analizie wpływu recesji na funkcjonowanie regionów, określaniu charakterystyk dotyczących zmian produktu krajowego brutto, zatrudnienia, inwestycji i in., a także na działaniach strategicznych i instrumentach stosowanych przez decydentów sfery publicznej, gospodarczej i społecznej. Do najczęściej stosowanych instrumentów należą zachęty inwestycyjne oraz działania na rynku pracy.

Słowa kluczowe: odporność gospodarcza, adaptatywność, podejście ewolucyjne.

Summary: The aim of the paper is to review the concept and research of economic resilience. There are three basic interpretations determining the scope of analysis: engineering, ecological and adaptive resilience. This concept explores whether the regions tend to equilibrium state, how they function as complex adaptive systems and how implemented strategies build their resilience to external disturbunces. Research in this area focuses on the analysis of the impact of the recession on the functioning of the regions, determining the characteristics of changes in gross domestic product, employment, investments and others as well as strategic activities and tools used by decision-makers of the public, economic and social institutions. The most commonly used instruments are investment incentives and labor market measures.

Keywords: economic resilience, adaptability, evolutionary approach.

\section{Wstęp}

Koncepcja odporności gospodarczej (resilience) coraz częściej jest przedmiotem dyskusji na świecie w badaniach naukowych, choć w literaturze polskiej zajmuje jeszcze niewiele miejsca. Z przeglądu badań wynika, że istnieją co najmniej trzy różne, lecz 
powiązane ze sobą, interpretacje odporności, które wpływają na definiowanie sposobu i zakres analizy w badaniach regionalnych [Martin 2012; Boschma 2015].

Pierwszą z nich jest odporność inżynieryjna (engineering resilience). Interpretacja ta zaadaptowana została z nauk fizycznych i skupia się na odporności systemu na szok oraz na szybkości powrotu do stanu sprzed negatywnego wpływu. Zakłada ona, że region/system jest odporny, jeśli następuje jego powrót do stanu równowagi.

Odporność ekologiczna (ecological resilience) skupia się na roli szoku/stresu lub zakłóceń wymuszających zmianę systemu poza posiadany przez niego próg elastyczności i powrót do równowagi, ale w nieco zmienionej formie. Interpretacja ta czerpie z nauk ekologicznych i opiera się na pracy Hollinga [1973], w której autor postrzega resilience jako zdolność systemu do wytrzymania stresu oraz reakcji na zewnętrzne zakłócenia. Interpretacja ta zakłada, że istnieje wiele stanów równowagi, które mogą być osiągnięte po zmianie funkcji lub struktury systemu.

Odporność adaptatywna (adaptive resilience) wywodzi się z teorii tzw. adaptatywnych systemów złożonych (complex adaptive systems). Zakłada się, że odporne systemy społeczno-gospodarcze potrafią w sposób ciągły reorganizować swe gospodarcze $\mathrm{i}$ instytucjonalne struktury. Odporność w tej interpretacji jest rozumiana raczej jako stały proces ewolucyjny aniżeli tylko odzyskanie lub ustanowienie nowego stabilnego stanu równowagi [Simmie, Martin 2010]. W odniesieniu do regionalnych gospodarek pojęcie to może być rozumiane jako odnoszące się do zdolności reorganizacji oraz adaptacji struktur i funkcji. W ramach odporności adaptatywnej wyróżnia się perspektywę instytucjonalno-funkcjonalną (agency perspective), gdzie identyfikuje się działania instytucji centralnych, samorządów, a także różnych instytucji gospodarczych i społecznych oraz określa się rolę liderów w budowaniu odporności gospodarczej.

\section{Koncepcje odporności gospodarczej}

Badania dotyczące odporności ekonomicznej skupiają się na poszukiwaniu odpowiedniego modelu gospodarki, który pozwala w sytuacjach kryzysowych, choć nie tylko, utrzymywać stabilny wzrost i rozwój. Wzrost taki powinien zmierzać do zachowania równowagi gospodarczej, społecznej i ekologicznej. Bazując na ww. interpretacjach odporności Pendall, Foster i Cowell [2010] przyjmują, że istnieją w debacie naukowej cztery tematy-metafory dotyczące resilience:

1. Equilibrium. W ramach tego podejścia zakłada się, że istnieje co najmniej jedna równowaga, a większość analiz wskazuje, że istnieje wiele równowag, do których powinny dążyć systemy społeczno-gospodarcze, w tym regiony. Bierze się pod uwagę sytuację związaną z recesją i określa się, czy po niej dany system wraca do stanu „normalnego” ( $\mathrm{tj}$. równowagi) lub czy nie zostanie szybko przekształcony i będzie zmierzał do nowej alternatywnej równowagi, często odległej w czasie.

2. Systems perspectives. Podejście to identyfikuje interakcje między instytucjami, w tym najważniejszymi aktorami politycznymi, gospodarczymi i społecznymi, 
a strukturą systemu. Podejście systemowe odnosi się do odporności adaptatywnej. Najczęściej jest wyjaśniane przez cztery fazy cyklu pozwalające się dostosować do wewnętrznych i zewnętrznych wyzwań. Każda z czterech faz - stabilizacja, uwolnienie, reorganizacja oraz eksploatacja - zachodzi w każdym systemie. Wskazuje się, że dany region doświadcza różnych poziomów odporności w zależności od tego, gdzie się znajduje w owym czterofazowym cyklu [Holling, Gunderson 2002; Cowell 2013]. Warto podkreślić, że podejście to nawiązuje w zasadzie do koncepcji twórczej destrukcji Schumpetera [1995].

3. Path dependence. Podejście to zakłada, że obserwowana w danym czasie równowaga systemu jest zależna od obranej wcześniej ścieżki rozwoju. Jest ona konsekwencją wcześniej podejmowanych skumulowanych decyzji, często realizowanych przez długi czas. Decyzje te mogą (lub nie) powodować, że system obierze właściwy kierunek rozwoju, który może prowadzić do określonego stanu równowagi.

4. The long view. W ramach owego podejścia odporność jest rozpatrywana w długim okresie i zawiera trzy ww. podejścia. Obserwuje się wówczas jeden lub więcej okresów stabilności. Poszukuje się owych punktów równowagi oraz wewnętrznej trwałej logiki badanych zjawisk. Zjawiska te nie są tylko społecznymi lub politycznymi procesami czy pojedynczymi wydarzeniami, lecz stanowią złożony i powiązany zależnościami ewoluujący system.

W badaniach dotyczących odporności regionalnej koncepcję tę określa się również mianem strategii. Bristow [2010] klasyfikuje dotychczasowe podejścia i proponuje nowe spojrzenie na politykę regionalną. Dotychczas większość strategii rozwoju regionalnego zasadniczo promuje konkurencyjność. Skutkiem tego jest duża zależność od niewielkiej liczby globalnie konkurujących firm oraz nacisk decydentów na przyciąganie inwestycji za wszelką cenę. W gospodarce widoczna jest silna zewnętrzna kontrola nad aktywami przedsiębiorstw, strategie ukierunkowane są na zewnętrznych odbiorców, a inwestorzy nastawieni na działania spekulacyjne. Ma również miejsce logika szybkiego wzrostu oraz nacisk na produktywność firm, często dużym kosztem społecznym. Model rozwoju regionu bywa w zasadzie ,importowany" i występuje silna zależność rozwoju od handlu zagranicznego i transportu. Strategia odporności zakłada natomiast większy udział społeczności lokalnej w zarządzaniu gospodarką, większy stopień usieciowienia i współodpowiedzialności za rozwój, wyższy poziom etyki w biznesie, a także zakłada dzielenie się nie tylko informacją, lecz również ryzykiem. Wspierane są małe i elastyczne przedsiębiorstwa, promowana jest terytorialna sprawiedliwość, a większego znaczenia nabiera współpraca i współdziałanie.

Wielość interpretacji odporności nie pozwala na sformułowanie jednej uniwersalnej definicji odporności. Sanots i Partidário [2011, s. 1519] podają złożoną definicję mówiącą, że odporność to inaczej „zdolność systemu (regionu, aktywności ekonomicznej, miasta, gospodarstwa domowego) do absorpcji zakłóceń i reorganizacji, które nie powodują jego upadku ani znaczących zmian jego tożsamości”. Inna definicja [Davoudi 2013, s. 302] wskazuje, że odporność może być określana mianem 
„Zdolności złożonego systemu społeczno-ekologicznego do zmian, adaptacji i transformacji w odpowiedzi na zakłócenia". Pojęcie odporności gospodarczej odnoszone bywa do uwarunkowań makroekonomicznych. Briguglio i in. [2009, s. 233] podają, że odporność gospodarcza to ,zdolność gospodarki do wyjścia z trudnej sytuacji gospodarczej wywołanej kryzysami zewnętrznymi lub zdolność dostosowania się do niej oraz wykorzystania pozytywnych impulsów". Autorzy wskazują, że odporność jest determinowana poprzez makroekonomiczną stabilność, deficyt fiskalny, inflację, bezrobocie i dług zewnętrzny. Wskazują oni także inne czynniki pozwalające budować odporność gospodarczą, a wśród nich efektywne mechanizmy rynkowe, sprawne rządzenie, rozwinięte i odpowiedzialne społeczeństwo posiadające wysokie kwalifikacje.

Eakin i Lemos [2006, s. 10] podają na podstawie wielu badań różnorodne czynniki dotyczące sfery społecznej, instytucjonalnej oraz fizycznego wyposażenia systemu w zasoby i kapitał, które decydują o odporności (zdolności do adaptacji) systemów (w tym regionów). Wśród nich wyróżniają, por. też [Zaucha i in. 2014]:

- Kapitał ludzki: wiedza (naukowa, techniczna, lokalna, polityczna), wykształcenie, zdrowie, praca, ryzyka indywidualne i ich postrzeganie.

- Informacja i technologia: sieci łączności, wolność ekspresji, wymiana informacji i transfer technologii, zdolności innowacyjne, systemy wczesnego ostrzegania, znaczenie technologii.

- Zasoby materialne i infrastruktura: transportowa i komunalna, gospodarka odpadami, jakość środowiska.

- Kapitał społeczny i zdolności organizacyjne: stosunki społeczeństwa obywatelskiego, lokalne sieci współpracy, mobilizacja społeczna, gęstość tkanki instytucjonalnej.

- Kapitał polityczny: modele zarządzania, przywództwo i jego legitymizacja, uczestnictwo, decentralizacja decyzji, potencjał zarządczy, suwerenność.

- Zasobność i kapitał finansowy: podział dochodu i bogactwa, marginalizacja ekonomiczna, dostępność instrumentów finansowych (ubezpieczenia, kredyty), fiskalne bodźce zarządzania ryzykiem.

- Instytucje i uprawnienia: formalne i nieformalne zasady ochrony zasobów, zarządzanie ryzykiem, uczestnictwo $\mathrm{w}$ regionalnych procesach planistycznych, dzielenie się informacjami, technologiczne innowacje, prawa własności, mechanizmy dzielenia się ryzykiem.

Koncepcja odporności gospodarczej wiąże się częściowo z koncepcją regionu inteligentnego. Badania bowiem pokazują, że mniejsza wrażliwość na kryzys cechuje sektory nowoczesne [Gorzelak (red.) 2009], które stanowią istotną cechę regionów inteligentnych. W badaniach dotyczących rozwoju inteligentnego uwaga skupiona jest na społecznych i instytucjonalnych aspektach wzrostu, takich jak procesy i mechanizmy uczenia się czy przekazywania wiedzy i innowacji [Nowakowska 2009]. Zwraca się szczególną uwagę na procesy imitacji i kreacji technologicznej, sprawność relokacji zasobów z sektorów schyłkowych do nowoczesnych oraz zdol- 
ność regionu do przekształcenia lokalnego systemu produkcyjnego w czasie recesji [Camagni 1995; Markowska 2014]. Koncepcja odporności gospodarczej jest natomiast szersza. Innowacyjność jest tylko jednym z elementów sprzyjających wyjściu z kryzysowej sytuacji czy pozwalających na długotrwały i stabilny rozwój. Oprócz determinant makroekonomicznych, o których piszą wspomniani Briguglio i in. [2009], oraz regionalnego systemu innowacji istotne znaczenie w tej koncepcji mają również nowoczesna i wydajna infrastruktura transportowa i komunikacyjna, przedsiębiorczy i innowacyjni pracownicy, system finansowy wspierający gospodarkę tanim i długoterminowym kredytem, zdywersyfikowana baza ekonomiczna [Christopherson $\mathrm{i}$ in. 2010] oraz aktywne i usieciowione społeczeństwo, charakteryzujące się wysokim poziomem kapitału społecznego [Adger 2000].

\section{3. Światowe i polskie badania odporności gospodarczej}

Badania z zakresu odporności gospodarczej prowadzone na świecie dotyczą konceptualizacji, a także próby ich zastosowania w badaniach regionalnych. Owe studia dotyczą wielu obszarów tematycznych i przestrzennych, wśród których można wymienić następujące tematy [Eraydin 2014]:

- Analiza szoków powodujących recesję i ich wpływ na zakłócenia regionalnych trajektorii wzrostu [Fingleton i in. 2012; Simmie, Martin 2010; Hill i in. 2008].

- Zmiana równowagi oraz zmiana wzorca rozwoju zależnego od wcześniej obranej ścieżki [Chapple, Lester 2010].

- Rozwój ewolucyjny regionów w połączeniu z nadchodzącymi zmianami poziomu krajowego i globalnego [Pendall i in. 2010].

- Relacje pomiędzy stroną publiczną, prywatną, sektorami ekonomii społecznej oraz wszelkiego rodzaju instytucjami [McInroy, Longlands 2010].

- Wpływ czynnika ludzkiego zarówno w formie indywidualnej, jak i zbiorowej, obejmujący różne skale organizacji, począwszy od działań jednostek, przez gospodarstwa domowe, społeczności, regiony aż po państwa [Davidson 2010; Sagan, Masik 2014].

- Wpływ recesji na regiony europejskie [Davies 2011], regiony Wielkiej Brytanii [Fingleton i in. 2012; Martin 2010], statystyczne obszary metropolitalne w USA [Hill $i$ in. 2008] lub centra IT [Gerst $i$ in. 2009].

W ramach projektu Economic Crisis: Resilience of Regions programu ESPON 2013 przebadano regiony obszaru ESPON, wskazując na te, które były odporne (resistant i recovered) oraz nieodporne (not recovered) na kryzys ekonomiczny. Wzięto pod uwagę głównie PKB oraz zatrudnienie. Uwzględniono cztery komponenty regionalnej odporności: ludność, społeczeństwo, gospodarkę oraz miejsce [Bristow i in. 2014; Sagan, Masik 2014].

$\mathrm{W}$ dotychczasowych badaniach prowadzonych w Polsce brano pod uwagę m.in. takie miary, jak PKB, nakłady na środki trwałe, inwestycje, wydajność pracy, wartość dodaną brutto oraz nakłady na działalność badawczo-rozwojową. Stosowano 
modele ekonometryczne oraz metodę klasyfikacji wielowymiarowej [Strahl i in. 2015; Strahl, Sokołowski 2014]. Badania obejmowały również ocenę wrażliwości regionalnych rynków pracy Unii Europejskiej na kryzys ekonomiczny [Markowska, Sobolewski 2014; Markowska 2014]. W innych badaniach określano odporność polskich regionów za pomocą wskaźnika odporności, biorąc pod uwagę zmiany PKB, zatrudnienia, dochodu rozporządzalnego, liczby podmiotów gospodarczych oraz przychodów z eksportu produktów innowacyjnych [Masik, Rzyski 2014].

W badaniach Churskiego i in. [2014] wzięto do analizy zestaw kilkudziesięciu wskaźników. Głównym celem było określenie prawidłowości wynikających ze zróżnicowanej wrażliwości i odporności na zmienność światowej koniunktury gospodarczej (w tym zjawisko kryzysu gospodarczego) obszarów wzrostu i obszarów stagnacji gospodarczej. Kompleksowa analiza objęła następujące jego aspekty: ludność i osadnictwo, rynek pracy i struktura gospodarki, infrastruktura techniczna i dostępność przestrzenna, sytuacja finansowa i poziom zamożności, innowacyjna gospodarka i otoczenie biznesu. W badaniu tym wykorzystano metodę analizy kanonicznej, metodę analizy trendów czasowych oraz metody analizy danych pozyskanych w drodze badań ankietowych.

$\mathrm{Z}$ reguły badania empiryczne opierają się na pomiarze wrażliwości gospodarek regionów, zmianach w międzynarodowym podziale pracy, eksporcie i wahaniach globalnej koniunktury [Gawlikowska-Hueckel, Szlachta (red.) 2014]. Został ponadto opracowany model pomiaru wrażliwości polskich regionów na zakłócenia i oddziaływania o charakterze makroekonomicznym [Zaucha i in. 2014]. Pomija się jednak zazwyczaj pozaekonomiczne kwestie wpływające na wzrost i rozwój, takie jak zmiany demograficzne, kapitał społeczny czy sprawność instytucjonalną. Z kolei nowsze badania prowadzone przez Celińską-Janowicz i Płoszaja [2015] zaczęły podejmować kwestię adaptatywności lokalnych gospodarek. Badania na szczeblu lokalnym, jak i regionalnym nie mają jednak jeszcze dobrze udokumentowanego i potwierdzonego waloru aplikacyjnego. Nie jest bowiem klarowne, jakiego rodzaju cechy systemów czy decyzje gwarantują budowanie odporności gospodarczej. Zbyt wiele zmiennych powiązanych $\mathrm{z}$ uwarunkowaniami konkretnego obszaru nie pozwala do tej pory, by wskazać uniwersalne prawidłowości, a także właściwe działania decydentów umożliwiające uniknąć kryzysu gospodarczego w danym układzie terytorialnym. Wskazuje się natomiast jedynie na te cechy gospodarek czy działania, które sprzyjają budowaniu odporności w długim okresie.

\section{Zakończenie}

W literaturze istnieje kilka podstawowych interpretacji odporności gospodarczej. Badania odnoszą się do odporności inżynieryjnej, ekologicznej oraz najczęściej adaptatywnej. W pracach nad odpornością stosowane jest podejście zmierzające do określenia równowagi, do jakiej region powinien zmierzać po okresie kryzysu. W perspektywie systemowej badania dotyczą zmian struktury gospodarczej i spo- 
łecznej regionów, a także stosowania instrumentów łagodzących skutki kryzysu bądź wspierających gospodarki w przyszłości. W badaniach określających odporność regionów analizuje się także strategie i decyzje podejmowane w przeszłości i ocenia się ich wpływ na funkcjonowanie regionów obecnie.

Przegląd badań pozwala stwierdzić, że najnowsze podejście (agency perspective) skupia się na identyfikowaniu najważniejszych instytucji gospodarczych i społecznych wspierających odporność oraz określaniu odpowiednich instrumentów. Instrumenty te obejmują najczęściej tworzenie pakietów gospodarczych dla firm czy inwestycje infrastrukturalne. Wspierana jest dywersyfikacja działalności gospodarczej oraz promowana innowacyjność i przedsiębiorczość. Stosowane są rozmaite zachęty podatkowe i inwestycyjne, jak zwolnienia z podatków na określony czas czy obniżanie wymiaru podatków. Zwiększana jest także dostępność kredytu i gwarancji kredytowych udzielanych przez instytucje publiczne. Sporo działań z zakresu budowania odporności gospodarczej dotyczy rynku pracy, w szczególności podnosi się kwestię elastycznych form zatrudnienia oraz szkoleń w miejscu pracy nie tylko dla bezrobotnych, lecz także dla pracowników w okresach przestoju działalności firm [Bristow i in. 2014; Masik, Sagan 2016]. Przeniesienie koncepcji resilience na poziom strategiczny, a szczególnie operacyjny, wymaga jednak dalszych pogłębionych badań.

\section{Literatura}

Adger W.N., 2000, Social and ecological resilience: are they related?, Progress in Human Geography, vol. 24 , no. 3, s. 347-364.

Boschma R., 2015, Towards an evolutionary perspective on regional resilience, Regional Studies, vol. 49, no. 5 , s. 733-751.

Briguglio L., Cordina G., Farrugia N., Vella S., 2009, Economic vulnerability and resilience: concepts and measurements, Oxford Development Studies, vol. 37, no. 3, s. 229-247.

Bristow G., 2010, Resilient regions: re 'place'ing regional competitiveness, Cambridge Journal of Regions, Economy and Society, vol. 3, s. 153-167.

Bristow G., Healy A., Norris L., Kafkalas G., Kakderi Ch., Swash A., Carey H., Sagan I., Masik G., Wink R., Kirchner L., Koch F., Speda D., Sensier M., Harding A., Espenberg K., Sepp V., Varblane U., 2014, ECR2 Economic Crisis: Resilience of Regions, ESPON Applied Research, Final Report, s. 110.

Camagni R., 1995, Espace et temps dans le concept de milieu innovateur, [w:] Rallet A., Torre A. (red.), Économie industrielle et économie spatiale, Paris, s. 193-210.

Celińska-Janowicz D., Płoszaj A., 2015, Rola samorząów w kształtowaniu potencjału adaptacyjnego lokalnych układów społeczno-gospodarczych - przykład Mazowsza, [w:] Celińska-Janowicz D., Płoszaj A. (red.), Rozwój lokalny w turbulentnym otoczeniu: mazowieckie samorzady wobec wyzwań adaptacyjności, Mazowiecka Jednostka Wdrażania Programów Unijnych, MGG Conferences Sp. z o.o, Warszawa, s. 4-52.

Chapple K., Lester T.W., 2010, The resilient regional labour market? The U.S. case, Cambridge Journal of Regions, Economy and Society, vol. 3, s. 85-104.

Christopherson S., Michie J., Tyler P., 2010, Regional resilience: theoretical and empirical perspectives, Cambridge Journal of Regions, Economy and Society, no. 1, s. 3-10. 
Churski P., Borowczak A., Dolata M., Dominiak J., Hauke J., Perdał R., Konecka-Szydłowska B., 2014, Zróżnicowanie wpływu światowej koniunktury gospodarczej w układzie obszarów wzrostu i obszarów stagnacji. Badanie wpływu światowej koniunktury gospodarczej (w tym zjawiska kryzy-su gospodarczego) na poszczególne aspekty rozwoju spoteczno-gospodarczego, Raport V, Po-znań.

Cowell M.M., 2013, Bounce back or move on: Regional resilience and economic development planning, Cities, vol. 30, s. 212-222.

Davidson D.J., 2010, The applicability of the concept of resilience to social systems: some sources of optimism and nagging doubts, Society and Natural Resources, vol. 23, no. 12, s. 1135-1149.

Davies S., 2011, Regional resilience in the 2008-2010 downturn: comparative evidence from European countries, Cambridge Journal of Regions, Economy and Society, vol. 4, s. 369-382.

Davoudi S., 2013, Resilience: A bridging oncept or a dead end?, Planning Theory and Practice, vol. 13 (2), s. 299-307.

Eakin H., Lemos M.C., 2006, Adaptation and the state: Latin America and the challenge of capacity-building under globalization, Global Environmental Change, vol. 16, s. 7-18.

Eraydin A., 2014, The importance of endogenous capacities and government support in the resilience of regions, 54th Congress of the European Regional Science Association: Regional development \& globalisation: Best practices, 26-29 sierpień 2014, St. Petersburg, Russia.

Fingleton B., Garresten H., Martin R., 2012, Recessionary shocks and regional employment: Evidence on the resilience of U.K. regions, Journal of Regional Science, vol. 52(1), s. 109-133.

Gawlikowska-Hueckel K., Szlachta J. (red.), 2014, Wrażliwość polskich regionów na wyzwania wspótczesnej gospodarki. Implikacje dla polityki rozwoju regionalnego, Wolters Kluwer SA, Warszawa.

Gerst J., Doms M., Daly M.C., 2009, Regional growth and resilience: evidence from urban IT centers, FRBSF Economic Review, s. 1-11.

Gorzelak G. (red.), 2009, Geografia polskiego kryzysu. Kryzys peryferii czy peryferia kryzysu, Regional Studies Association, Warszawa.

Hill E.W., Wial H., Wolman H., 2008, Exploring Regional Economic Resilience, Working Paper 2008-04, Institute of Urban and Regional Development, Berkeley.

Holling C.S., 1973, Resilience and stability of ecological systems, Annual Review of Ecology and Systematics, vol. 4, s. 2-23.

Holling C.S., Gunderson L.H., 2002, Resilience and Adaptive Cycles, [w:] Lance H. (red.), Human and Natural Systems, Island Press, Washington, D.C., s. 25-62.

Markowska M., 2014, Ocena zależności między rozwojem inteligentnym a odpornościa na kryzys ekonomiczny w wymiarze regionalnym - przegląd badań, [w:] Strahl D., Raszkowski A., Głuszczuk D. (red.), Gospodarka regionalna w teorii i praktyce, Prace Naukowe Uniwersytetu Ekonomicznego we Wrocławiu, nr 333, s. 22-32.

Markowska M., Sobolewski M., 2014, Wrażliwość regionalnych rynków pracy Unii Europejskiej na kryzys ekonomiczny. Klasyfikacja metoda Warda z warunkiem spójności, Acta Universitatis Lodziensis. Folia Oeconomica, vol. 6 (308), s. 87-103.

Martin R., 2010, Regional economic resilience, hysteresis and recessionary shocks, Journal of Economic Geography, vol. 12, no. 1, s. 1-32.

Masik G., Rzyski S., 2014, Resilience of Pomorskie region to economic crisis, Bulletin of Geography. Socio-economic Series, no. 25, s. 129-141.

Masik G., Sagan I., 2016, Strategie i instrumenty wspierające odporność gospodarcza regionów. Przykład wybranych regionów europejskich, Studia Regionalne i Lokalne, nr 4 (66), s. 5-29.

McInroy N., Longlands S., 2010, Productive local economies: Creating resilient places, CLES-Centre for Local Economic Strategies, Manchester [maszynopis].

Nowakowska A., 2009, Regionalny kontekst procesów innowacji, [w:] A. Nowakowska (red.), Budowanie zdolności innowacyjnych regionów, Wydawnictwo Biblioteka, Łódź, s. 19-41. 
Pendall R., Foster K., Cowell M., 2010, Resilience and regions: building understanding of the metaphor, Cambridge Journal of Regions, Economy and Society, vol. 3, s. 1-14.

Sagan I., Masik G., 2014, Economic resilience. The case study of Pomorskie region, Raumforschung und Raumordnung, Bericht aus Forschung and Praxis, vol. 72, s. 153-164.

Santos F., Partidário M., 2011, SPARK: Strategic planning approach for resilience keeping, European Planning Studies, vol. 19 (8), s. 1517-1536.

Schumpeter J., 1995, Kapitalizm, socjalizm, demokracja, Wydawnictwo Naukowe PWN, Warszawa.

Simmie J., Martin R., 2010, The economic resilience of regions: towards an evolutionary approach, Cambridge Journal of Regions, Economy and Society, vol. 3, s. 27-43.

Strahl D., Markowska M., Sokołowski A., Sobolewski M., 2015, Klasyfikacja dynamiczna regionów Unii Europejskiej szczebla NUTS 2 z uwagi na wrażliwość na kryzys ekonomiczny (obszar: zmiany w gospodarce), Prace Naukowe Uniwersytetu Ekonomicznego we Wrocławiu, nr 393, s. 32-44.

Strahl D., Sokołowski A., 2014, Propozycja podejscia metodologicznego do oceny zależności między inteligentnym rozwojem a wrażliwościa na kryzys ekonomiczny w wymiarze regionalnym, Prace Naukowe Uniwersytetu Ekonomicznego we Wrocławiu, nr 331, s. 190-200.

Zaucha J., Ciołek D., Brodzicki T., Głazek E., 2014, Wrażliwość polskich regionów na wyzwania gospodarki globalnej, [w:] Gawlikowska-Hueckel K., Szlachta J. (red.), Wrażliwość polskich regionów na wyzwania wspótczesnej gospodarki. Implikacje dla polityki rozwoju regionalnego, Wolters Kluwer SA, Warszawa, s. 206-244. 